\title{
Nutritional and Physicochemical Characteristics of Foxtail Millet Genotypes
}

\author{
Shilpa Huchchannanavar ${ }^{1 *}$, L.N. Yogesh ${ }^{2}$ and S.M. Prashant ${ }^{2}$ \\ ${ }^{1}$ ICAR-KrishiVigyan Kendra ${ }^{2}$ Agricultural Research Station, Hagari, Ballari-583111 \\ University of Agricultural Sciences, Raichur, India \\ *Corresponding author
}

A B S T R A C T

\section{Keywords}

Millet, Nutrition,

Health, Fat, Fibre,

Protein

Article Info

Accepted:

12 December 2018

Available Online:

10 January 2019

\begin{abstract}
Nutritional and physico-chemical properties are very important factors in food product development in this regard a study was carried out to know the nutritional and physicochemical characteristics of nine foxtail millet genotypes developed at Agricultural Research Station, Hagari along with the check variety. The genotype HN-46 recorded highest 1000 grain weight. The volume of thousand grains was high inHN-13 $(2.5 \mathrm{ml})$. The bulk density of ten genotypes ranged from 0.75 to 2.20 . The protein content of HMT 100$1(13.29 \mathrm{~g})$ was high among all the genotypes followed by HN-43 genotypes $(13.10 \mathrm{~g})$, The fat content of HMT 100-1 was high (3.83) whereas the lowest fat content was in the genotype HN-43 (2.80). The crude fibre in HN-43 was more (2.98) whereas the total mineral content was high in Sia3162 and HN-46 (2.0g). The Energy value of HMT100-1 (3.79) was high compared to other genotypes. The low calorific value was noted in HN-46 and Sia 2644 (363 Kcal).
\end{abstract}

\section{Introduction}

Millets are the super grains with reservoirs of nutrients. Millets were indeed oldest foods known to humans. Due to rice and wheat obsession these crops were neglected from past few years. Millets are major food sources for millions of people, especially those who live in hot, dry areas, hilly region with low rain fall. India is the largest millet producing country in the world with a total area of 23 million ha and these nutri-cereals alone account for about 3.5 million hectare (Stanly and Shanmugam, 2013). The major millets are pearl millet, foxtail millet, proso-millet, little millet and finger millet. Among the millets foxtail millet is underutilized grain grown across the world. It grows well even under adverse agro-climatic conditions. Foxtail millet is non-glutinous and non-acid farming and easy to digest. Foxtail millet is also a good source of energy, fats, proteins, fatty acids, vitamins, minerals and dietary fibre. Foxtail millet proteins contain good sources of essential amino acids except lysine and threonine but have relatively high quantity of sulphur containing amino acids (methionine and cysteine). Foxtail millets are rich sources of phytochemicals, micronutrients and antioxidants, such as phenolic acids and 
glycated flavonoids. Foxtail millets, with their low Glycemic index value, high dietary fibreand water soluble gum content (b-glucan) have been attributed to improve glucose metabolism. These grains release sugar slowly to blood. The dietary fibre and resistant starch of these nutri-cereals have been attributed to exhibit hypoglycemic and hypolipidemic effects. Millet grains have antioxidative properties against oxidative stress, which is mainly determined by their higher reserves of phytochemicals like phenolics, tannins, phytates and micro minerals etc. Because of the high nutritive value and the functional ingredients present in it, foxtail millet is considered as neutraceutical grain. An experiment was conducted to evaluate the genotypes developed at Agricultural Research Station, Hagari, University of Agricultural sciences, Raichur for their physico-chemical and cooking qualities.

\section{Materials and Methods}

Ten foxtail millet genotypes (including check) developed at Agricultural Research Station, Hagari were used for present study and the experiment was conducted at ICAR-Krishi Vigyana Kendra, Ballari.

\section{Physical characteristics}

Ten Foxtail Millet genotype samples were assessed for physical characteristics viz., thousand-kernel weight, volume and bulk density. Thousand grains were randomly selected from a well-mixed sample and weighed. The volume of 1000 grains was determined by water displacement method (William et al., 1983). In brief, the grains were added to a known volume of water in a graduated flask. The difference between the initial and final volume indicates the volume of the seeds. The ratio between the weights of 1000 grains to its volume was calculated as bulk density.

\section{Cooking characteristics}

\section{Cooking time}

Cooking time of each millet genotype was determined by boiling $2.0 \mathrm{~g}$ of whole millet grains from each millet genotypes in $20 \mathrm{ml}$ of distilled water, removing a few grains at different time intervals during cooking and pressing them between two glass plates until no white core was left. Optimum cooking time was taken as the established cooking time plus two additional minutes.

\section{Water uptake ratio}

The water uptake ratio was determined by cooking $2.0 \mathrm{~g}$ of whole millet grain from each genotype in $20 \mathrm{ml}$ distilled water for a minimum cooking time in a boiling water bath and drain the superficial water from the cooked millet.

The cooked samples were weighed accurately and the water uptake ratio was calculated as the ratio of final cooked weight to uncooked weight of the grain and converted to percentage.

Water uptake ratio $=($ weight of cooked millet sample/ weight of uncooked millet samples) $\mathrm{x}$ 100.

\section{Solids in cooked water}

Solids in cooked water were determined by drying an aliquot of the cooked water in an evaporating dish to evaporate the water. The weight of the empty petri dish (W1) and weight of petri dish with aliquot (W2) was recorded. The petri dish with aliquot was kept at hot air oven till complete drying of water from the solids. The weight of petri dish with aliquot after drying was recorded as (W3). The amount of solid in cooking water was calculated as W3-W1. 


\section{Grain elongation during cooking}

Grain elongation during cooking was determined by calculating the difference in grain length before and after cooking. The length of ten grains of each millet type was recorded and the average was calculated. The grain length before cooking was noted as (L0) and after cooking was noted as (L1). Grain elongation was then calculated as L1-L0.

Nutritional composition of foxtail millet genotypes (Dry weight basis /100g)

Proximate principles i.e., moisture, crude protein, crude fat, crude fibre, carbohydrate, total mineral matter (ash) and energy of the genotypes were analyzed according to AOAC 1980 and 1990 procedures.

\section{Results and Discussion}

Physical characteristics generally influence the functional and organoleptic characteristics. They were studied using standard procedures. The physical parameters like weight (g) 1000 grains, volume, bulk density and colourof foxtail millet genotypes were presented in Table 1. Significant difference was observed among foxtail millet genotypes for thousand grain weight. The genotype HN-46 recorded highest 1000 grain weight of $2.81 \mathrm{~g}$ followed by HMT100-1 $(2.57 \mathrm{~g})$. The volume of thousand grains was $2.5 \mathrm{ml}$ in $\mathrm{HN}-13$ followed by Dhftmv-313, Dhft2-5, HN-45, HN-46, HN43 and HMT 100-1 (2.0 ml). The bulk density of ten genotypes ranged from 0.75 to 2.20 . Among the genotypes Sia-326 showed higher bulk density of 2.20 followed by genotype Dhftmv 2-5 (1.9) and Sia-3162 (1.5). Where check genotype Sia-264 showed lower bulk density of 0.75 . In a study conducted by Thilagavathi and co-workers (2015) thousand grain weights of the selected millets was found to be high in pearl millet $(11.39 \mathrm{~g} / 100 \mathrm{~g})$ compared to kodo millet, proso millet and little millet $(2.45,2.43$ and $2.23 \mathrm{~g} / 100 \mathrm{~g}$, respectively). The genotypes HN-13, DHftmv235, Sia-3162, Sia-326 and Sia-2644 showed creamish seed colour whereas HN-45, HN-46 and HMT 100-1 were creamish dull in color. The genotype Dhfmv 333 was observed to be Brownish cream in seed color. Nutritional composition of foxtail millet per $100 \mathrm{~g}$ edible portion according to (Gopalan et al., 2007) is proteins $(12.3 \mathrm{~g})$, carbohydrates $(60.9 \mathrm{~g})$, fat $(4.3 \mathrm{~g})$, crude fibre $(8.0 \mathrm{~g})$, calcium $(31 \mathrm{mg})$, minerals $(3.3 \mathrm{~g})$ and thiamin $(0.59 \mathrm{mg})$. Foxtail millet is one of the minor millets containing high amounts of proteins (12.3\%) and minerals (3.3\%) (Vithal and Machewad, 2006). Foxtail millet is twice richer in protein (10 to $15 \%$ ) compared to rice (6 to $9 \%$ ).

\section{Cooking qualities of foxtail millet genotypes}

The genotype DHftmv, HN-45, Sia2644 took longer time to cook (11 minutes) compared to other genotypes (Table 2). Whereas water uptake ratio was high in Dhftmv 333, HN-45, HN-46, Sia 2644(260\%) compared to other varieties. The low water uptake ratio was observed in DHftmv 2-5 and Sia326 (245\%). The percent solids in cooking was high in DHftmv 333, HN-46, HN-45, Sia 326, Sia 2644 (25\%) compared to other varieties however the difference was non- significant. Grain elongation was more in $\mathrm{HN}-13$, DHFtmv 2-5, Sia 3162, HN-45, HN46, HN43, HMT100-1, Sia 2644 i.e., 5 per cent compared to other genotypes.

\section{Nutritional composition}

Since nutritional well-being is the dynamic force for development of human genetic potential, nutritional quality of food should be taken care for maintaining human health (Radhika et al., 2011). Millets are unique among the cereals because of their richness in calcium, dietary fibre, polyphenols and protein (Devi et al., 2011). In the present study the 
nutritional composition of ten different genotypes was estimated using standard methodologies and is presented in Table 3. The maximum moisture content among the selected genotypes was observed in $\mathrm{HN}-13$ i.e., 9.65g followed by HMT100-1 genotype $(9.60 \mathrm{~g})$ and the minimum was noted in $\mathrm{H} 45$ genotypes $(8.90 \mathrm{~g})$. Kulkarni and Naik reported that proso millet recorded a high moisture content ranging from 10.60 to 15.00 per cent, followed by little, foxtail and kodo millet with values of $10.7,11.5$ and 10.2 per cent, respectively.

Table.1 Physical characteristics of foxtail millet genotypes

\begin{tabular}{|l|c|c|c|c|}
\hline \multicolumn{1}{|c|}{ Variety } & $\begin{array}{c}\text { Weight (g) 1000 } \\
\text { grains }\end{array}$ & $\begin{array}{c}\text { Volume } \\
(\mathbf{m l})\end{array}$ & $\begin{array}{c}\text { Bulk Density } \\
(\mathbf{W t / V o l})\end{array}$ & Colour \\
\hline HN-13 & 2.52 & 2.50 & 1.00 & Creamish \\
\hline DHftmv 333 & 2.43 & 2.00 & 1.21 & Brownish cream \\
\hline DHFtmv2-5 & 2.05 & 2.00 & 1.97 & Creamish \\
\hline Sia 3162 & 2.26 & 1.50 & 1.50 & Creamish \\
\hline HN-45 & 2.50 & 2.00 & 1.25 & Creamish dull \\
\hline HN-46 & 2.81 & 2.00 & 1.40 & Creamish dull \\
\hline HN-43 & 2.25 & 2.00 & 1.12 & Creamish bright \\
\hline Sia326 & 2.20 & 1.00 & 2.20 & Creamish \\
\hline HMT 100-1 & 2.57 & 2.00 & 1.28 & Creamish dull \\
\hline Sia 2644 & 2.00 & 1.50 & 0.75 & Creamish dull \\
\hline \multicolumn{1}{|c|}{ SEm } & 0.07 & 0.06 & 0.03 & \\
\hline CD & 0.20 & 0.17 & 0.10 & \\
\hline CV & 5.00 & 5046 & 4.17 & \\
\hline
\end{tabular}

Table.2 Mean value of cooking qualities of foxtail millet genotypes

\begin{tabular}{|l|c|c|c|c|}
\hline \multicolumn{1}{|c|}{ Variety } & $\begin{array}{c}\text { Cooking time } \\
\text { (Min) }\end{array}$ & $\begin{array}{c}\text { Water uptake } \\
\text { ratio }(\mathbf{\%})\end{array}$ & $\begin{array}{c}\text { Solids in cooking } \\
(\mathbf{\%})\end{array}$ & $\begin{array}{c}\text { Grain elongation } \\
(\mathbf{\%})\end{array}$ \\
\hline HN-13 & 10.00 & 250 & 2.4 & 5.00 \\
\hline DHftmv 333 & 11.00 & 260 & 2.5 & 4.50 \\
\hline DHFtmv2-5 & 10.00 & 245 & 2.4 & 5.00 \\
\hline Sia 3162 & 10.00 & 250 & 2.4 & 5.00 \\
\hline HN-45 & 11.00 & 260 & 2.4 & 5.00 \\
\hline HN-46 & 10.00 & 260 & 2.5 & 5.00 \\
\hline HN-43 & 10.00 & 250 & 2.5 & 4.00 \\
\hline Sia326 & 10.00 & 245 & 2.5 & 4.00 \\
\hline HMT 100-1 & 10.00 & 250 & 2.3 & 5.00 \\
\hline Sia 2644 & 11.00 & 260 & 2.5 & 5.00 \\
\hline SEm & 0.29 & 2.18 & 0.04 & 0.26 \\
\hline CD & 0.86 & 6.47 & 0.13 & 0.76 \\
CV & 4088 & 1.49 & 3.13 & 9.36 \\
\hline
\end{tabular}


Table.3 Nutritional composition of foxtail millet genotypes (Dry weight basis 100g)

\begin{tabular}{|c|c|c|c|c|c|c|c|}
\hline Genotype & $\begin{array}{l}\text { Moisture } \\
\text { (g) }\end{array}$ & $\begin{array}{l}\text { Protein } \\
\text { (g) }\end{array}$ & $\begin{array}{l}\text { Fat } \\
(g)\end{array}$ & $\begin{array}{l}\text { Crude } \\
\text { fibre (g) }\end{array}$ & $\begin{array}{c}\text { Carbohydrate } \\
\text { (g) }\end{array}$ & $\begin{array}{c}\text { Total } \\
\text { minerals }(\mathrm{g})\end{array}$ & $\begin{array}{l}\text { Energy } \\
\text { (Kcal) }\end{array}$ \\
\hline HN-13 & 9.65 & 11.50 & 3.35 & 2.06 & 72.40 & 1.28 & 366 \\
\hline $\begin{array}{l}\text { DHftmv } \\
333\end{array}$ & 9.39 & 12.98 & 2.98 & 2.23 & 73.45 & 1.20 & 368 \\
\hline $\begin{array}{l}\text { DHFtmv2- } \\
5\end{array}$ & 9.23 & 11.32 & 3.62 & 2.13 & 71.60 & 1.50 & 364 \\
\hline Sia 3162 & 9.52 & 12.50 & 3.52 & 2.56 & 72.65 & 2.00 & 372 \\
\hline HN-45 & 8.90 & 12.35 & 2.96 & 2.30 & 74.00 & 1.89 & 372 \\
\hline HN-46 & 9.20 & 12.10 & 3.10 & 2.40 & 73.00 & 2.00 & 363 \\
\hline HN-43 & 9.40 & 13.10 & 2.80 & 2.98 & 72.23 & 1.98 & 367 \\
\hline Sia326 & 9.23 & 12.50 & 3.20 & 2.10 & 71.20 & 1.53 & 364 \\
\hline $\begin{array}{l}\text { HMT 100- } \\
1\end{array}$ & 9.60 & 13.29 & 3.83 & 1.95 & 72.73 & 1.33 & 379 \\
\hline Sia 2644 & 9.31 & 12.10 & 2.85 & 2.10 & 72.20 & 1.90 & 363 \\
\hline SEM & 0.10 & 0.35 & 0.06 & 0.04 & 0.50 & 0.04 & 2.14 \\
\hline CD & 0.30 & 1.03 & 0.19 & 0.11 & 1.49 & 0.10 & 6.34 \\
\hline CV & 1.86 & 4.86 & 3.34 & 2.76 & 1.19 & 3.68 & 1.01 \\
\hline
\end{tabular}

The protein content of HMT $100-1(13.29 \mathrm{~g})$ was high among all the genotypes followed by $\mathrm{HN}-43$ genotypes $(13.10 \mathrm{~g})$, whereas lowest protein content was observed in DHftmv2-5 genotype which is $11.32 \mathrm{~g}$. The fat content of HMT 100-1 was high (3.83) followed by DHFtmv2-5 (3.62). The lowest fat content was in the genotype HN-43 (2.80). The crude fibre content of $\mathrm{HN}-43$ was more (2.98) compared to other genotypes whereas HMT100-1 (1.95) showed less crude fibre content among all the varieties tested. Carbohydrate content was high in HN-45 (74) followed by DHftmv $333(73.45 \mathrm{~g})$ whereas low carbohydrate content was noted in Sia326 $(71.20 \mathrm{~g})$. The total mineral content was high in Sia3162 and HN-46 (2.0g) whereas low total mineral content was observed in DHftmv333 (1.20 g). The Energy value of HMT100-1 (3.79) was high compared to other genotypes followed by Sia 3162 and HN-45 (372Kcal). The low calorific value was noted in HN-46 and Sia 2644 (363 Kcal). Thippeswamy et al., (2017) has observed the range of values for grain nutrients content among the selected genotypes, where protein content(6.2-10.89\%), zinc content (2.29-11.4 $\mathrm{mg} / 100 \mathrm{~g})$, iron content (0.33 to 16.26 $\mathrm{mg} / 100 \mathrm{~g}$ ) and calcium content were (1.99 to $22.69 \mathrm{mg} / 100 \mathrm{~g}$ ). Doddamani and Yenagi (2018) studied the effect of pre-treatments on nutritive value of foxtail millets wherein different pre-treatments were given to the millet grains in different combination such as roasting; cooking, drying and roasting. Pretreatment reduced the moisture, protein, fat content of millet grains significantly $(\mathrm{p}<$ $0.05)$.

More reduction was observed in cooked, dried and roasted grains and minimum reduction was observed in roasted grains. There was no significant difference observed in ash content. Carbohydrate content increased more in cooked, dried and roasted grains (62.14 g) than roasted grains $(56.77 \mathrm{~g})$. Roasting increased insoluble dietary fibre $(12.95 \mathrm{~g})$ and total dietary fibre $(13.60 \mathrm{~g})$ whereas it decreased in cooked, dried and roasted grains 
(10.70 and $11.05 \mathrm{~g}$ ). Nutritional wellbeing is a sustainable force for health and development and maximization of human genetic potential. The nutritional status of a community has therefore been recognized as an important indicator of national development. In other words, malnutrition is an impediment in national development and hence assumes the status of national problem. For solving the problem of deep-rooted food insecurity and malnutrition, dietary quality should be taken into consideration.

It is concluded from the present study, the genotypes of foxtail millets having diversity for nutritional composition and the genotypes identified from our study were source for addressing the malnutrition and health benefits for human.

\section{References}

AOAC 1980, Official methods of Analysis, 11th edition. 2004. Association of Official Agricultural Chemists, Washington, DC.

AOAC 1990, Official methods of Analysis, 11th edition. 2004. Association of Official Agricultural Chemists, Washington, D, C.

Devi, P. B., R. Vijayabharathi, S. Sathyabama, N.G. Malleshi and V. B. Priyadarisini. 2011. Health benefits of finger millet (Eleusine coracana L.) polyphenols and dietary fiber: a review. J. Food Sci. Technol. DOI:10.1007/s13197-011-0584-9.

Doddamani, S and Yenagi, N.B., 2018., Nutrient Composition of Pre-treated Foxtail Millet Rice., International Journal of Microbiology and Applied Sciences.7(2): 1314-1322.
Gopalan, C., Ramasashtri, B.V and Balasubramanian, S.C. 2007. Nutritive Value of Indian Foods. National Institute of Nutrition, ICMR: Hyderabad, India, p. 47.

Kulkarni LR, Naik RK. 2009., Composition of minor millets. Journal of Agricultural Sciences. 8(1): 88-92.

Radhika G, Sathya RM, Ganesan A, Saroja R, Vijayalakshmi P and Sudha A. 2011. Dietary Profile of Urban Adult Population in South India in the Context of Chronic Disease Epidemiology (CURES-68). J. Public Health Nut. 14(4): 591-598.

Stanly JMP, Shanmugam A. 2013. A study on millets based cultivation and consumption in India. International Journal of Marketing, Financial Services and Management Research. 2(4): 49-58.

Thilagavathi T., Kanchana, S., Bhanumati, P., Hemalatha, G., Vanniarajan C., Sundar, M and lamaran, M., 2015. Indian Journal of Science and Technology, Vol 8(S7), 147-155.

Thippeswamy, V., Sajjanar, G.M., Nandini, C., Bhat, S and Doddaraju, P., 2017. Characterization of Genotypes for Nutritional traits in Foxtail Millet [Setaria italica (L.) Beauv.]. International Journal of Microbiology and Applied Sciences. 6(12): 97-101.

Vithal, D. P., and Machewad, G. M., 2006. Processing of foxtail millet for improved nutrient availability. J. Food Process. Preserv. 30: 269-279.

William, P. C., Nakoul, H., and Singh, K. B., 1983. Relationship between cooking time and some physical characteristics in chickpea (Cicer arietinum L.). J. Sci. Food Agri. 34: 492-496.

\section{How to cite this article:}

Shilpa Huchchannanavar, L.N. Yogesh and S.M. Prashant. 2019. Nutritional and Physicochemical Characteristics of Foxtail Millet Genotypes. Int.J.Curr.Microbiol.App.Sci. 8(01): 1773-1778. doi: https://doi.org/10.20546/ijcmas.2019.801.188 